\title{
BILLY BAXTER: A BEACON FOR CAUSATION IN PRIVATE ANTITRUST SUITS
}

The plaintiff in a private antitrust suit under section 4 of the Clayton Act' carries a difficult burden of persuasion in establishing the requisite causation between the antitrust violation and the resulting injury. Due to general judicial disfavor of the private antitrust suit, ${ }^{2}$ judges have seized the connection between the injury and the violation as the primary ground upon which to deny standing to sue for treble damages. ${ }^{3}$ The tests to determine standing used by the courts have usually been couched in terms of physical causation, obscuring the policy decisions that should have been confronted. ${ }^{4}$ In Billy Baxter, Inc. v. Coca-Cola Co. ${ }^{5}$ the Court of Appeals for the Second Circuit has stated the most explicit standards of any court for determining whether a private antitrust plaintiff has the necessary causative link to the alleged violation for standing to sue. The implications of the analysis used in Billy Baxter on the present guidelines for standing will be discussed in this note.

The Sherman $\mathrm{Act}^{6}$ was the first far-reaching legislation prohibiting both unreasonable restraints upon and monopolization of trade. Neither the broad wording of the Act nor the Congressional history yields an instructive standard for prospective plaintiffs, aside from an inference that the remedy "is given to the party damnified." Section 4 of the Clayton Act was enacted to enlist the aid of private parties in the struggle against restraints on free competition and to compensate injured parties by authorizing the recovery of treble damages. ${ }^{8}$ Unless a defendant's action has an adverse effect on the

I. 15 U.S.C. $\$ 15$ (1964).

2. Entire classes of plaintiffs have been denied standing, although they come within a literal reading of section 4 . See notes $22-30 \mathrm{infra}$ and accompanying text.

3. See Billy Baxter, Inc. v. Coca-Cola Co., 431 F.2d 183, 187 (2d Cir. 1970), cert. denied. 401 U.S. 923 (1971); Molinas v. National Basketball Ass'n, 190 F. Supp. 241, 243 (S.D.N.Y. 1961).

4. Most opinions determine the injury to be "indirect" without considering the policy reasons for denying standing. See notes 19-34 infra and accompanying text.

5. 431 F.2d 183 (2d Cir. 1970), cert. denied, 401 U.S. 923 (1971).

6. 26 Stat. 210 (1890), as amended, 15 U.S.C. $\S \S 5-7$ (1964).

7. See, e.g., 21 CONG. REC. 1767 (1890).

8. See Minnesota Mining \& Mfg. Co. v. New Jersey Finishing Co., 381 U.S. 311,320 (1965); Bruce's Juices, Inc. v. American Can Co., 330 U.S. 743, 751-52 (1947); Atlantic City Electronic Co. v. General Elec. Co., 226 F. Supp. 59,71 (S.D.N.Y. 1964); Cinnamon v. Abner A. Wolf. Inc.. 215 F. Supp. 833, 834 (E.D. Mich. 1963); Hess v. Anderson, Clayton \& Co., 20 F.R.D. 466 (S.D. Cal. 1957). 
economy by substantially lessening competition in a significant share of the appropriate market, no redress is given to a party injured by the action. ${ }^{9}$ The authorization for a private suit established by section 4 reads:

Any person who shall be injured in his business or property by reason of anything forbidden in the antitrust laws may sue therefor . . . without respect to the amount in controversy, and shall recover three fold the damages by him sustained, and the cost of suit, including a reasonable attorney's fee. ${ }^{10}$

The allowance of treble damages was the primary reason recovery was not extended to give a right of action based solely on unreasonable market power, ${ }^{11}$ even though the treble remedy was usually considered remedial and not penal. ${ }^{12}$ Since a literal interpretation of section 4 would result in an extremely broad category of potential plaintiffs, the courts have limited recovery. By restricting the scope of "business or property" 13 and by construing "by reason of" to require the plaintiff

9. See Dole Valve Co. v. Perfection Bar Equip., Inc., 311 F. Supp. 459, 462 (N.D. Ill. 1970); Rayco Mfg. Co. v. Dunn, 234 F. Supp. 593,597 (N.D. IIl. 1964); Gomberg v. Midvale Co., 157 F. Supp. 132, $141-42$ (E.D. Pa. 1955).

10. Clayton Act $\S 4,15$ U.S.C. $\S 15$ (1964) (emphasis added).

11. See C. Kaysen \& D. Turner, Antitrust Pol.icy: An Economic and Legal. Analysis 258. 271 (1959). There must be a causal connection between the injury and the antitrust violation. American Infra-Red Radiant Co. v. Lambert Indust., Inc., 360 F.2d 977, 996 (8th Cir. 1966).

12. Vold, Are Threefold Damages Under the Anti-trust Act Penal or Compensatory?. 28 Ky. L.J. 117, 147-48, 157 (1940). The Supreme Court has declared: "Where the statute provides ... for a recovery of damages for an act which violates the rights of the plaintiff. and gives the right of action solely to him, the fact that it also provides that such damages shall not be less than a certain sum . . . does not . . . transform it into a penal statute." Brady v. Daly, 175 U.S. 148, 156 (1899). See also Huntington v. Attrill, 146 U.S. 657,668 (1892). While courts have disagreed over the characterization of treble damages for antitrust violations, the majority view considers this remedy more compensatory than penal in nature. Normal Tobacco \& Candy Co. v. Gillette Safety Razor Co., 197 F. Supp. 333, 335 \& n. 10 (N.D. Ala. 1960), affd. 295 F.2d 362 (5th Cir. 1961). See Atlanta v. Chattanooga Foundry \& Pipeworks Co.. 127 F. 23, 28.29 (6th Cir. 1903), affd. 203 U.S. 390 (1906); cf. Herald Co. v. Harper, 410 F.2d 125, 130-31 (8th Cir. 1969); Crummer Co. v. duPont, 223 F.2d 238, 246-47 (5th Cir. 1955), rev'g and rem' 117 F. Supp. 870 (N.D. Fla. 1954), cert. denied. 350 U.S. 848 (1955). But see Westíngliouse Elec. Corp. v. Burlington, 351 F.2d 762, 770 (D.C. Cir. 1965); Johnson v. Joseph Schlitz Brcwing Co., 33 F. Supp. 176, 182 (E.D. Tenn. 1940), affd per curiam. 123 F.2d 1016 (6th Cir. 1941).

13. Most controversies arise concerning businesses which have not yet been established, and the degree of "preparedness" is used to decide whether the business has developed to the point where treble damages are in order. See Pennsylvania Sugar Ref. Co. v. American Sugar Ref. Co., 166 F. 254, 260 (2d Cir. 1908) (expensive refinery built in anticipation of entering the business); Deterjet Corp. v. United Aircraft Corp.. 211 F. Supp. 348, 353 (D. Del. 1962) (application for a patent and investors willing and able to start the enterprise). See generally Note. Standing to Sue for Treble Damages Under Section 4 of the Clavion Act. 64 Coulw. L. Rev. 570, 577-81 (1964); E. Timberlake. Federal. Treble- Damage ANtitrust actions $\S 4.01$ (1965) [hereinafter cited as TIMBERLAKE]. 
to allege and prove the causal connection between the injury and the antitrust violation, ${ }^{14}$ the standards for suit were made very strict. An obvious method of determining if the causation is established would be the "foreseeability" test that is applied to negligence actions in tort law. ${ }^{15}$ However, the law has not developed under this test due to the absence of standards of antitrust injury against which the injury of the plaintiff can be compared. ${ }^{16}$ Consequently, in proving that the aggrieved party would have been better off but for the alleged misdeeds, a conjectural reconstruction of past economic history is required. Another factor opposing a test of foreseeability is that no comparable "duty" element, which delineates how far the violator's damage liability should be extended, is present in the antitrust laws. ${ }^{17}$ As one author has stated, private recovery "must be considered in terms of 'injury' or 'causation,' or it cannot be considered at all." 18

\section{Directness Test}

One theory developed to restrict the broad wording of section 4 is the "derivative loss" or "direct injury" concept, ${ }^{19}$ in which losses resulting from the impairment of a business relationship with an entity that was the victim of an antitrust violation are deemed too remote to allow recovery. The injury must "directly" result to the plaintiff; i.e., it must not be the consequence of an injury to someone else. ${ }^{20}$ Therefore, an interruption or diminution of profitable relations is not enough to warrant treble damages unless the injured party has had business contact with the violator. ${ }^{21}$ The directness test has been extended to deny standing to the following: officers, ${ }^{22}$ stockholders ${ }^{23}$

14. Dailey v. Quality School Plan, Inc., 380 F.2d 484, 487 (5th Cir. 1967); Dole Valve Co. v. Perfection Bar Equip., Inc., 311 F. Supp. 459, 462 (N.D. IIl. 1970).

15. W. Prosser, The LAw of Torts 288 (3d ed. 1964).

16. Pollock, The "Injury" and "Causation" Elements of a Treble-Damage Antitrust Action. 57 Nw. U.L. Rev. 691, 694-95 (1963).

17. Id. at 700 .

18. Id.

19. See Denver Petroleum Co. v. Shell Oil Co., 306 F. Supp. 289, 306-07 (D. Colo. 1969); SCM Corp. v. Radio Corp. of America, 276 F. Supp. 373, 376 (S.D.N.Y. 1967); Sperry Prods., Inc. v. Aluminum Co. of America, 171 F. Supp. 901,938 (N.D. Ohio 1959); $c$. Rossi v. McCloskey \& Co., 149 F. Supp. 638, 640 (E.D. Pa. 1957).

20. See, e.g., Bookout v. Schine Chain Theatres, Inc., 253 F.2d 292 (2d Cir. 1958); Peter v. Western Newspaper Union, 200 F.2d 867 (5th Cir. 1953); Snow Crest Beverages, Inc. v. Recipe Foods, Inc., 147 F. Supp. 907 (D. Mass. 1956).

21. See Denver Petroleum Corp. v. Shell Oil Co., 306 F. Supp. 289, 309 (D. Colo. 1969).

22. See Westmoreland Asbestos Co. v. Johns-Manville Corp., 30 F. Supp. 389 (S.D.N.Y. 1939), affd. 113 F.2d 114 (2d Cir. 1940).

23. See Walker Distrib. Co. v. Lucky Lager Brewing Co., 323 F.2d 1, 10 (9th Cir. 1963); 
and creditors ${ }^{24}$ of an injured corporation; a landlord of an injured lessee; ${ }^{25}$ a supplier of an injured dealer, ${ }^{26}$ even when under common ownership; $;^{27}$ a patent owner who licensed the patent to an injured licensee; $;^{28}$ an insurance agent representing an injured underwriter; ${ }^{20}$ and a franchisor who licensed an injured franchisee..$^{30}$ Most of these cases utilized a proximate cause analysis, ${ }^{31}$ withholding liability whenever a third party intervened between the antitrust violation and the injured party.

Courts initially denied standing because of judicial wariness of multiple recoveries and a dislike of numerous small suits when one action by the corporation would give adequate relief. ${ }^{32}$ While courts have based their denial of standing on a lack of direct injury to plaintiff's business, it is not always clear from the language of the opinions whether this denial is based on the plaintiff's inability to show physical causation or the court's unwillingness to place the plaintiff within the court's conception of the zone of foreseeability. ${ }^{33}$ Persistent, confusing, and sometimes interchangeable use of such terms as physical causation, proximate cause, and zone of

Loeb v. Eastman Kodak Co., 183 F. 704, 709 (3d Cir. 1910); Ames v. American Tel. \& Tel. Co., 166 F. 820, 822-23 (C.C.D. Mass. 1909).

24. See Loeb v. Eastman Kodak Co., 183 F. 704, 709 (3d Cir. 1910); Klebanow v. New York Produce Exch., 232 F. Supp. 965,967 (S.D.N.Y. 1964).

25. See Lieberthal v. North Country Lanes, Inc., 221 F. Supp. 685, 690 (S.D.N.Y. 1963), affd, 332 F.2d 269 (2d Cir. 1964); Melrose Realty Co. v. Loew's, Inc., 234 F.2d 518 (3d Cir.), cert. denied, 352 U.S. 890 (1956). But cf. Congress Bldg. Corp. v. Loew's, Inc., 246 F.2d 587 (7th Cir. 1957).

26. See, e.g., Volasco Prods. Co. v. Lloyd A. Fry Roofing Co., 308 F.2d 383, 395 (6th Cir. 1962). But see South Carolina Council of Milk Producers, Inc. v. Newton, 360 F.2d 414 (4th Cir.), cert. denied, 385 U.S. 934 (1966).

27. See, e.g., Snow Crest Beverages, Inc. v. Recipe Foods, Inc., 147 F. Supp. 907 (D. Mass. 1956).

28. See Productive Inventions, Inc. v. Trico Prods. Corp., 224 F.2d 678 (2d Cir. 1955), cerf. denied. 350 U.S. 936 (1956).

29. See, e.g.. Miley v. John Hancock Mut. Life Ins. Co., 148 F. Supp. 299 (D. Mass.), aff'd, 242 F. $2 \mathrm{~d} 758$ (1st Cir.), cert. denied. 355 U.S. 828 (1957).

30. See Billy Baxter, Inc. v. Coca-Cola Co., 431 F.2d 183 (2d Cir. 1970); Nationwide Auto Appraiser Serv., Inc. v. Association of Cas. \& Sur. Cos., 382 F.2d 925 (10th Cir. 1967).

31. See, e.g.. South Carolina Council of Milk Producers, Inc. v. Newton, 360 F.2d 414, 419. 20 (4th Cir.), cert. denied. 385 U.S. 934 (1966); Association of W. Rys. v. Riss \& Co., 299 F.2d 133, 135 (D.C. Cir. 1962); Data Digests, Inc. v. Standard \& Poor's Corp.. 43 F.R.D. 386,387 (S.D.N.Y. 1967). See also Burkhead v. Phillips Petroleum Co., 308 F. Supp. 120, 123 (M.D. Cal. 1970).

32. Loeb v. Eastman Kodak Co., 183 F. 704.709 (3d Cir. 1910).

33. See Duff v. Kansas City Star Co., 299 F.2d 320 (8th Cir. 1962); Sperry Prods.. Inc. v. Aluminum Co. of America, 171 F. Supp. $901,938-39$ (N.D. Ohio 1959); Gomberg v. Midvale Co., 157 F. Supp. 132. $141-42$ (E.D. Pa. 1955). 
foreseeability has only blurred the question of standing and has resulted in courts concentrating on definitional problems instead of antitrust policy considerations. However, some decisions have given the policy considerations on which their conclusions were based. One court noted the drastic nature of the treble damage remedy when the plaintiff is only incidentally harmed and the elimination of numerous small actions when one suit by the corporation would give relief. Moreover, the court feared imposing six-fold liability if both shareholders and the corporation institute treble damage actions. ${ }^{34}$ Policy justification is the exception rather than the rule, however, with most decisions holding the injury indirect because the plaintiff was within one of the classes previously held to lack standing.

\section{Target Area Test}

A method that has recently gained wide recognition in deciding standing problems is the "target area" approach, ${ }^{35}$ which focuses on whether the person injured by the antitrust violation was "aimed at" and "hit" by the illegal activity. ${ }^{36}$ The plaintiff must show he is within the area of the economy endangered by the competitive breakdown ${ }^{37}$ and has been injured due to the lessened competition. The most influential case in this area is Karseal Corp. v. Richfield Oil Corp., ${ }^{38}$ in which a manufacturer of car wax was determined to have standing to sue Richfield Oil Corporation, who had entered into contracts with service stations that prevented Karseal products from being used. Even though independent distributors handled the car wax between Karseal and the service stations who were forced to stop using the wax, the fact that the product discriminated against was manufactured by Karseal enabled the court to find the requisite causative connection between the injured market and the plaintiff. Recent cases have been more explicit in their application of the test.

34. See, e.g.. Loeb v. Eastman Kodak Co., 183 F. 704, 709 (3d Cir. 1910); Snow Crest Beverages, Inc. v. Recipe Foods, Inc., 147 F. Supp. 907,909 (D. Mass. 1956).

35. See generally TimberLA Ke $§ 4.03$; Pollock, Standing to Sue. Remoteness of Injury, and the Passing-On Doctrine. 32 A.B.A. AntrTrust L.J. 5, 17 (1966); Pollock, supra note 16, at 703.

36. Mulvey v. Samuel Goldwyn Prod's., 433 F.2d 1073, 1076 (9th Cir. 1970); Schulman v. Burlington Indus., Inc., 255 F. Supp. 847, 85 I (S.D.N.Y. 1966).

37. See Dole Valve Co. v. Perfection Bar Equip., Inc., 311 F. Supp. 459, 462 (N.D. Ill. 1970); Kirihara v. Bendix Corp., 306 F. Supp. 72, 90 (D. Hawaii 1969); Rayco Mfg. Co. v. Dunn, 234 F. Supp. 593,597 (N.D. Ill. 1964).

38. 221 F.2d 358 (9th Cir. 1955), noted in 104 U. PA. L. REv. 543 (1956). See also Conference of Studio Unions v. Loew's Inc., 193 F.2d 51 (9th Cir. 1951). 
For example, in Kirihara v. Bendix Corp. ${ }^{39}$ the District Court of Hawaii held that an automotive oil filter distributor, whose lease was terminated following the merger of the lessor and an automobile parts manufacturer, lacked standing to sue the manufacturer, inasmuch as no lessening of competition in the automobile oil filter market resulted from the merger. The effect of the transfer of the lease was held to be outside the target area, which the court held was the market for oil filters rather than their retail sales. The test adopted by the Kirihara court involved two inquiries. First, the injury must be directly and proximately caused by the antitrust violation, a factor shown by illustrating the reasonable probability that a substantial anticompetitive effect in the market would flow from the antitrust violation. Second, the injured plaintiff must be one of the components of the competitive infrastructure of the relevant market involved. The effect of an injury to a component of minimal, i.e., non-effective, competitive significance is not within the target area. Even though the emphasis in the target area test is on the vigor of competition in the market ${ }^{30}$ rather than hardship to individual businessmen," the parties to the private antitrust action need not be competitors. ${ }^{42}$ Proving a significant decrease in the level of competition is in itself, however, a heavy burden for the plaintiff to carry in a typically complex market. ${ }^{43}$

The target area test probably represents the most rational method of cutting off liability for injuries caused by the widening ripples that flow from an antitrust violation. ${ }^{44} \mathrm{~A}$ correct application of this test requires an examination of the purpose of the defendant's conduct and the nature of the prohibition, ${ }^{45}$ factors often overlooked under the directness test. However, the exclusive use of the target area test has been criticized as a limitation on the court's analytical flexibility. ${ }^{46} \mathrm{An}$ examination of the results of applying the several standing tests to

39. 306 F. Supp. 72 (D. Hawaii 1969).

40. See Report of the attorney General's National Comm. to Study the ANTITRUST LAWS 164-66 (1955).

41. Id.

42. See Billy Baxter. 1nc. v. Coca-Cola Co.. 431 F.2d 183, $188-89$ (2d Cir. 1970): Hoopes v. Union Oil Co.. 374 F.2d 481, 486 (9th Cir. 1967): Mctropolitan Liquor Co. v. Heublein, Inc., 305 F. Supp. $946.948-49$ (E.D. Wis. 1969).

43. See, e.g. Mead's Fine Bread Co. v. Moore, 208 F.2d 777 (10th Cir. 1953), rev'd on other grounds, 348 U.S. 115 (1954). See also TIMBERLAKE $§ 17.07$.

44. Pollock, supra note 16. at 706-07.

45. Pollock, supra note 35, at 19.

46. Note. 64 CoLlim. L. Rev.. supra note 13. at 587 n.132. 
specific situations gives a better insight into the state of flux that currently envelops the law of standing in private antitrust suits.

\section{Classes of Plaintiffs Traditionally Denied Standing}

Shareholders, officers and creditors of an injured corporation. The courts have generally held that the shareholders, officers, and creditors of a corporation injured by an antitrust violation lack standing to maintain a personal action against the violator. ${ }^{47}$ Because of the corporation's position between the plaintiff and the violator, courts have deemed the injury remote, incidental, or indirect. ${ }^{48}$ For example, in Loeb v. Eastman Kodak Co. ${ }^{.9}$ a shareholder-creditor was denied standing to sue for antitrust violations against his corporation, the court holding that the injury was too far removed from the loss incurred by the corporation to allow treble damages. The courts followcd the general corporate rule that a stockholder of a corporation has no personal right of action against third persons for a wrongful injury recoverable by the corporation..$^{50}$ Later cases have followed this rule, even when the corporation is dissolved and unable to sue. ${ }^{51}$

Recently an officer has been allowed to sustain a personal action under section 4 of the Clayton Act for loss of employment due to antitrust violations against the employer-corporation. ${ }^{52} \ln$ Data Digests, Inc. v. Standard \& Poor's Corp. ${ }^{53}$ the president and also sole stockholder of a corporation was held to have standing to sue for

47. See Wälker Distrib. Co. v. Lucky Lager Brewing Co., 323 F.2d 1, 10 (9th Cir. 1963); Peter v. Western Newspaper Union, 200 F.2d 867, 872-73 (5th Cir. 1953); Roseland v. Phister Mfg. Co.. 125 F.2d 417, 419 (7th Cir. 1942); Centanni v. T. Smith \& Sons, lnc., 216 F. Supp. 330, 338 (E.D. La.), affd. 323 F.2d 363 (5th Cir. 1963); New Sanitary Towel Supply, Inc. v. Consolidated Laundries Corp., 211 F. Supp. 276, 277-80 (S.D.N.Y. 1962); Walder v. Paramount Publix Corp., 132 F. Supp. 912, 916 (S.D.N.Y. 1955).

48. See. e.g. Martens v. Barrett, 245 F.2d 844, 848 (5th Cir. 1957); Peter v. Western Newspaper Union, 200 F.2d 867, 872-73 (5th Cir. 1953); Loeb v. Eastman Kodak Co., 183 F. 704, 709 (3d Cir. 1910); New Sanitary Towel Supply, Inc. v. Consolidated Laundries Corp., 211 F. Supp. 276 (S.D.N.Y. 1962).

49. Loeb v. Eastman Kodak Co., 183 F. 704 (3d Cir. 1910).

50. See United Copper Sec. Co. v. Amalgamated Copper Co., 244 U.S. 261, 264 (1917); Dewing v. Perdicaries, 96 U.S. 193 (1877).

51. See New Sanitary Towel Supply, Inc. v. Consolidated Laundries Corp., 211 F. Supp. 276 (S.D.N.Y. 1962).

52. See Nichols v. Spencer Int'l Press, Inc., 371 F.2d 332, 334 (7th Cir. 1967); Schroeter v. Ralph Wilson Plastics, Inc., 49 F.R.D. 323 (S.D.N.Y. 1969); Data Digests, Inc. v. Standard \& Poor's Corp., 43 F.R.D. 386 (S.D.N.Y. 1967); $c$. Radovich v. National Football League, 352 U.S. 445 (1957).

53. 43 F.R.D. 386 (S.D.N.Y. 1967). 
treble damages based on salary decreases, extra hours worked, and lost vacations which were necessary to save the corporation from financial failure due to defendant's antitrust violation. No policy justification for the decision was given aside from judicial notice of the trend toward more liberal criteria for standing. However, other jurisdictions have not followed the Data Digests holding and have limited their section 4 actions for loss of employment to situations where the plaintiff has developed his corporate operations to the extent that the court views the business as his personally. ${ }^{54}$ Even with this limitation, the courts have progressed from summarily disposing of standing issues toward evincing a liberal trend in deciding standing for private antitrust actions. ${ }^{55}$

Lessors of an injured lessee. Generally, a lessor who is entitled to a percentage of the lessee's gross receipts lacks standing to sue for injuries caused by antitrust violations that diminished the lessee's gross receipts. ${ }^{56}$ The directness test has primarily been applied, resulting in a holding of "remote injury" because of the interposition of the lessee. ${ }^{57}$ An exception results when the conspiracy has forced the lessor to take action which directly diminished the value of his property, such as forcing the lessor to grant a less favorable lease than could be obtained on the open market. ${ }^{58} \mathrm{~A}$ second exception has been made to the general rule when the lessee was a party to the antitrust conspiracy since this results in privity between the plaintiff and the lessee-conspirator. ${ }^{59}$ But the logic of the directness test breaks down at this point, since other lessors whose lessees were not involved in the conspiracy, but whose injuries are identical, are denied standing. The Second Circuit, in a more consistent analysis, has held the lessor

54. Dailey v. Quality School Plan, Inc., 380 F.2d 484, 487 (5th Cir. 1967).

55. It should be noted, however, that the limitation on the shareholder's personal action does not prohibit derivative suit brought in favor of the corporation. See generally Annot., 36 A.L.R.2d 1345, 1346-51 (1954).

56. See Timberlake § 4.06; Timberlake. The Legal Injury Requirements and Proof of Damages in Treble Damage Actions Under the Antitrust Laws, 30 GEo. WaSH. L. Rev. 231, 247-49 (1961); Note. The Franchisor as Plaintiff in Treble Damage Actions: An Antitrust Anomaly, 49 B. U.L. Rev. 322, 328 (1969).

57. See Melrose Realty Co. v. Loew's, Inc., 234 F.2d 518 (3d Cir.), cert. denied, 352 U.S. 890 (1956): Lieberthal v. North Country Lanes, Inc., 221 F. Supp. 685, 690 (S.D.N.Y. 1963); Harrison v. Paramount Pictures. Inc., I I5 F. Supp. 312 (E.D. Pa. 1953), aff d, 211 F.2d 405 (3d Cir.). cert. denied. 348 U.S. 828 (1954).

58. See, e.g., Steiner v. Twentieth Century-Fox Corp., 232 F.2d 190, 194 (9th Cir. 1956).

59. See Congress Bldg. Corp. v. Loew's. Inc., 246 F.2d 587. $594-95$ (7th Cir. 1957); Steiner v. Twentieth Century-Fox Corp.. 232 F.2d 190 (9th Cir. 1956); Erone Corp. v. Skouras Theat res Corp.. 166 F. Supp. 62 I. 624 (S.D.N.Y. 1957). 
always too remote to maintain a treble damage action, even if the lessee is a conspirator. ${ }^{60}$

Suppliers of an injured manufacturer or dealer. Suppliers of an unfinished product have been denied standing to sue under section 4 for lost profits caused by competition-related injuries to the buyer of its products, ${ }^{61}$ even when the buyer is the only customer of the supplier. ${ }^{62}$ Recognizing that the injury to the supplier was foreseeable, ${ }^{63}$ courts have denied standing because of a fear of subjecting businessmen to liability of indefinite scope, Congressional approval of the restricted reading of section 4 as evidenced by legislative silence, and a reluctance to allow recovery for an injury resulting more "directly" to a separate legal personality. ${ }^{64}$ However, in Karseal Corp. v. Richfield Oil Corp ${ }^{65}$ a manufacturer of a finished product was held to have standing to sue a corporation that entered into restrictive contracts with the ultimate distributors of the plaintiff's product. Holding the existence of an intermediate distributor irrelevant, the Ninth Circuit applied the target area test and determined that plaintiff's product was within the auto wax market threatened by the competitive breakdown. The fact that Karseal supplied a finished product established a substantive connection between Karseal and the area of injured competition, indicating a fulfillment of the requirement of physical causation. By requiring the plaintiff to be both "aimed at" and "hit" by the antitrust violation, an application of the Karseal test should demand an investigation into the purpose of the misconduct and whether the injury is of the type the antitrust laws are designed to discourage. The analysis used avoided the quagmire of proximate cause or directness but did require an explicit consideration of the policy issues involved. ${ }^{66}$

Franchisor of an injured franchisee. Several circuit courts have held that a franchisor lacks standing to sue under section 4 for lost

60. See Lieberthal v. North Country Lanes, Inc., 221 F. Supp. 685 (S.D.N.Y. 1963), affd, 332 F.2d 269 (2d Cir. 1964).

61. See note 26 supra.

62. See Snow Crest Beverages, Inc. v. Recipe Foods, Inc., 147 F. Supp. 907 (D. Mass. 1956).

63. Id. at 909 .

64. Id.

65. 221 F.2d 358 (9th Cir. 1955). See note 38 supra and accompanying text.

66. The target area test has often been applied in a confused manner. For example, in South Carolina Council of Milk Producers, Inc. v. Newton, the Fourth Circuit adopted the target area test and then discussed the standing issue in terms of proximate cause. $360 \mathrm{~F} .2 \mathrm{~d} 414,419-20$ (4th Cir. 1966). See Pollock, supra note 35, at 19 n.63. 
royalties caused by antitrust violations that injured the franchisees. ${ }^{67}$ In Billy.Baxter, Inc. v. Coca-Cola Co ${ }^{68}$ a franchisor of bottled beverages, Billy Baxter, was denied standing to sue for lost profits caused by injuries to its franchisees allegedly resulting from agreements between competing bottlers and the franchisees' customers that gave incentives not to use Billy Baxter products. The Second Circuit held that the franchisor's connection with the franchisees' business lacked the substantive ties necessary to recover treble damages. The opinion emphasized that Billy Baxter specifically denied agency in the franchise contract and did not qualify to do business in three of the four states in which the franchisees operated. The quality control inspections that Billy Baxter conducted were held to be primarily for determining the size of royalties instead of protecting the plaintiff's trademark. The court found irrelevant the fact that the franchisor and the antitrust violators were competitors in the soft drink market, since the plaintiff did not have a substantive involvement in the relevant market of bottled beverages. Judge Anderson, writing for the majority, reasoned that the antitrust laws can be an effective deterrent to those businessmen contemplating a violation of the antitrust laws only if the laws can be administered with some degree of certainty. Fearing that vague rules of causation would threaten a relaxation of the standard of business behavior enforced by the treble recovery, ${ }^{69}$ his examination revealed that the causal connection between the injury and the antitrust violation was insubstantial.

In a perceptive dissenting opinion, Judge Waterman noted that the early cases denying standing were decided when courts were very hesitant to impose liability on corporations where no privity existed between the plaintiff and corporate defendant. ${ }^{70}$ Thereafter stare decisis had the effect of denying recovery to classes of plaintiffs regardless of the policy issues involved in such a decision. However, noting a new trend with the development of the target area test which swept away the direct-indirect criteria and focused on the effect of the

67. See Billy Baxter, Inc. v. Coca-Cola Co., 431 F.2d 183, 188 (2d Cir. 1970); Nationwide Auto Appraiser Serv., Inc. v. Association of Cas. \& Sur. Cos., 382 F.2d 925. 929 (10th Cir. 1967). See generally 49 B. U.L. REv., supra note 56, at 322.

68. 431 F.2d 183 (2d Cir. 1970).

69. See Schwartz v. Broadcast Music, Inc., 180 F. Supp. 322, 325 (S.D.N.Y. 1959).

70. Judge Waterman noted that "those were the days when "privity" was king and even MacPherson v. Buick Motors [217 N.Y. 382. 111 N.E. 1050 (1916)] had not been written." 431 F.2d at 190. 
injury on the relevant market, ${ }^{71}$ the dissent differed from the majority's interpretation of Billy Baxter's connection with the relevant market. Judge Waterman stated that the brand name and secret formulae used by the franchisees identified the plaintiff with the bottled products. Furthermore, since the Lanham $\mathrm{Act}^{72}$ has been interpreted to give a franchisor comprehensive duties to insure uniform standards of quality, ${ }^{73}$ Judge Waterman felt this duty established the plaintiff's close ties with the injured market.

The majority in Billy Baxter examined the causal connection between the injury and the violation, requiring the violation to be a "substantial factor" of the damages involved. ${ }^{74}$ A direct physical involvement was required, whereas the dissenting opinion stated that the effect of using the trademark, resulting in product identification and a duty to insure quality, was enough to establish the causal connection required for standing. Billy Baxter is an example of a correct application of the target area test, especially since it enables a subsequent reappraisal of the reasons for denying standing instead of requiring a perplexing inquiry into direct or proximate cause.

\section{The Application of Billy Baxter to Other Classes of Plaintiffs}

The Billy Baxter analysis of a franchisor-plaintiff's involvement in the area of the marketplace adversely affected by the defendant's activity applies equally well to the previously discussed classes of plaintiffs who have traditionally been denied standing. For example, a substantial corporate shareholder who actively participates in the management of the company would seem to satisfy the Billy Baxter requirements, ${ }^{75}$ especially if the corporation refuses to pursue the action or has been dissolved. ${ }^{76}$ Likewise, lessors who are substantively involved in the operations of their lessees to increase royalty payments

71. See Sanitary Milk Producers, Inc. v. Bergjans Farm Dairy, Inc., 368 F.2d 679, 688-89 (8th Cir. 1966); South Carolina Council of Milk Producers, Inc. v. Newton, 360 F.2d 414 (4th Cir.), cert. denied, 385 U.S. 934 (1966); Karseal Corp. v. Richfield Oil Corp., 221 F.2d 358 (9th Cir. 1955).

72. Lanham Act $\S 5,15$ U.S.C. $\S 1055$ (1964).

73. Alligator Co. v. Robert Bruce, Inc., I76 F. Supp. 377 (D.C. Pa. 1959).

74. 431 F.2d at 187.

75. In many close corporations the formality of having directors run the business is disregarded, and the shareholders actually perform corporate functions. See DEL. CODE ANN. tit. $8, \S 351$ (1968), which allows the stockholders to abolish the board of directors of a close corporation.

76. This would cure the loophole now existing when the corporation has been dissolved. See note 51 supra. 
should also be able to prove their involvement in the market that is the lessee's business. ${ }^{77}$ This may not widen the class of possible plaintiffs, since recovery against a conspiring lessee by the lessor would be denied unless the lessor met the "substantive involvement" test. ${ }^{77}$ This standard would cure the anomalous situation created by the present "directness" test. ${ }^{79}$ The "finished product" test applied in Karseal" would be a corollary to the Billy Baxter standard since a substantive connection might be established by product identification. Similarly, a supplier who supervises the use, control, or advertising of his product such that he is physically involved in the area of injured competition should have standing to try his case on the merits. ${ }^{81}$ His injury is just as predictable and harmful to competition as an injury to the buyer.

The Billy Baxter test gives the courts increased flexibility of analysis when re-evaluating the causative connection as the policy of the law changes. Initially, a strict rule will probably be followed, giving results concurrent with the present tests. However, since the recent trend is toward a more liberal standard, ${ }^{82}$ transitions can be rationalized on policy grounds under the Billy Baxter test. Without the type of approach in Billy Baxter, a change in judicial position is from "indirect injury" to "direct injury" under identical fact situations, usually resulting in muddled analysis.

\section{Summary Disposition}

When the causative connection has been held to be insufficient to support a treble damage action, summary judgment under Rule 56 of the Federal Rules of Civil Procedure is in order. ${ }^{83}$ Yet, the Suprenie Court has cautioned against disposing of antitrust litigation without giving the plaintiff full opportunity to formulate his charges. ${ }^{\text {gh }}$ Several

77. See notes 56-60 supra and accompanying text.

78. See note 59 supra and accompanying text.

79. See notes 59-60 supra and accompanying text. Courts may be reluctant to follow the analysis this far, since there is something sinister about a lessee conspiring against the lessor. But the logic of the antitrust laws requires no exception.

80. See notes 65-66 supra and accompanying text.

81. If the plaintiff in Billy Baxter had introduced more evidence of his active involvement in the franchisee's market the Second Circuit may have granted standing. 431 F.2d at 189.

- 82. See notes 53, 58-59 and 65 supra and accompanying text.

83. Summary judgment is appropriate when no genuine issue remains for trial. FED. R. CIv. P. 56(c). See Poller v. Columbia Broadcasting System. 368 U.S. 464, 467 (1962); Associated Press v. United States, 326 U.S. 1. 6 (1945): Sartor v. Arkansas Nat'l Gas Corp., 32I U.S. 620. 627 (1944). See generally TIMBERLAKE \$§ 12.01-.07.

84. Radovich v. National Football League, 352 U.S. 445 (1957). 
factors support a sparing use of summary judgment in this context: the serious nature of the charges, the defendants' control of the proof, ${ }^{85}$ the presence of hostile witnesses, and difficulty in discovery. ${ }^{86}$ However, it has been asserted that summary judgment procedure should be used less "sparingly" in antitrust cases, perhaps due to a desire to curb vexatious suits and excessively long trials. ${ }^{87}$

\section{Other Remedies}

A party injured by an antitrust violation has the alternative action of suing the violator in tort for malicious injury to business. ${ }^{88}$ This action requires only a "but-for" test of causation, ${ }^{89}$ which is much more relaxed than even the target area test. The plaintiff need only prove that the defendant acted with the intent of harming the plaintiff, the acts were not privileged, and that these acts resulted in the plaintiff's harm. ${ }^{90}$ Some competitive torts are presumptively suspect, such as a concerted refusal to deal, since they destroy the competitive system's internal checks. ${ }^{91}$ Recovery for these torts is allowed upon a showing of malice ${ }^{92}$ or coercion..$^{93}$ In addition, punitive damages can raise the recovery to treble damage levels. ${ }^{94}$

Although the existence of a common law remedy does not foreclose a treble damage action, ${ }^{95}$ it can help fill the gap created by

85. See Curto's Inc. v. Krich-New Jersey, Inc., 193 F. Supp. 235, 238 (D.N.J. 1961).

86, See Philco Corp. v. Radio Corp. of America, 34 F.R.D. 453 (E.D. Pa. 1964).

87. Poller v. Columbia Broadcasting System, 368 U.S. 464, 478 (1962) (dissenting opinion of Justice Harlan).

88. See, e.g., French v. United States Fidelity \& Guar. Co., 88 F. Supp. 714,721 (D.N.J. 1950). See generally Note, 49 B. U.L. Rev., supra note 56, at 338-39; Developments in the Law-Competitive Torts, 77 Harv. L. Rev. 888, 959-69 (1964); Comment, 37 Mich. L. Rev. 115 (1938); Note, Tortious Interference with Conduct of a Business. 56 YALE L.J. 885 (1947).

89. See Neumann v. Bastian-Blessing Co., 71 F. Supp. 803, 805 (N.D. Ill. 1946); R. Calliman, The LaW of Unfair Competition Trademarks and Monopolies $\$ 87.1$ (a)(2), at $4 \mathrm{I}-42$ (3d ed. 1970).

90. Bruce Lincoln-Mercury, Inc. v. Universal C.1.T. Credit Corp., 325 F.2d 2, 13 (3d Cir. 1963).

91. See Developments in the Law-Competitive Torts, supra note 88, at 929.

92, See, e.g., Delz v. Winfree, 80 Tex. 400, 405, 16 S.W. 111,112 (1891).

93. See, e.g.. Martell v. White, 185 Mass. 255, 261-62, 69 N.E. 1085, 1088 (1904).

94. See Allison v. American Airlines, 112 F. Supp. 37 (N.D. Okla. 1953). In Pierce Ford Sales, Inc. v. Ford Motor Co., 299 F.2d 425 (2d Cir. 1962), the district court had awarded compensatory damages of $\$ 10,000$, and exemplary damages of $\$ 13,850$. Although this was reversed on appeal, it indicates the potentiality of damage awards.

95. Mulvey v. Samuel Goldwyn Prod., 433 F.2d 1073, 1075 (9th Cir. 1970), cert. denied, 402 U.S. 923 (1971). If both antitrust and common-law claims are brought as alternative actions, the common-law claim may be sustained even though the antitrust claim is dismissed. Mackey v. Sears, Roebuck \& Co., 237 F.2d 869 (7th Cir. 1956). 
strict federal standing requirements. By simultaneously commencing the common law action as an alternative to the antitrust claim, the private plaintiff can protect himself from a denial of recovery without a trial on the merits.

\section{Conclusion}

As a matter of antitrust policy, it is unfair for private litigants to collect treble damage awards for conduct the illegality of which cannot be readily determined in advance. ${ }^{96}$ Also, since the cost of antitrust litigation is extremely high and proof of damages is difficult, ${ }^{97}$ it is desirable to have rules of standing that enable a fairly accurate prediction of the outcome of a treble damage action. Although the directness test provides a clear-cut standard, it lacks the flexibility necessary to consider policy issues and creates the hazard that courts will apply it without investigating individual fact situations. ${ }^{98}$ The target area test, as applied in Billy Baxter, is the most rational approach yet developed, since it requires the courts to examine the plaintiff's connection to the market and to focus on the precise reasons why standing was granted or denied..$^{99}$

Requiring a substantive connection between the plaintiff and the area of injured competition is perhaps the best compromise between the conflicting objectives of effective administration of the private antitrust action and compensating those injured by violations. Not only does proof of damages tend to become speculative when the relationship between the injured party and the market grows tenuous, ${ }^{100}$ but court time is more likely to be wasted in frivolous suits.

96. C. Kaysen \& D. Turner, Antitrust Policy: An Economic and Legal analysis 257 (1959).

97. See generally Alioto. The Economics of a Treble Damage Case, 32 A.B.A. ANTITRUST L.J. 87 (1966); McConnell. Proof of Damages in an Antitrust Case, 7 ANtitrust Bull. 39 (1962).

98. Most courts find plaintiff's injury in these cases "remote." "indirect," or "consequential," which will in turn, without a more in-depth analysis of the actual fact situation. dictate the outcome of the case. In Billy Baxter Judge Waterman, dissenting, castigated this approach as "label disposition." 431 F.2d at 191.

99. There is a more precise statement of the test given in Note. 64 ColuM. L. REv.. supra note 13. at 587. where emphasis is placed upon both the "competitive effects" and the "substantive connection."

100. Difficulty in ascertaining damages is not a defense to an antitrust action, but is a relevant factor in deciding the standing issue. Story Parchment Co. v. Paterson Parchment Paper Co.. 282 U.S. 555, 565 (1931). The damage may be reasonably approximated if based on competent evidence. Bigelo v. RKO Radio Pictures, Inc.. 327 U.S. 251, 264 (1946); American Infra-Red Radiant Co. v. Lambert Indus.. Inc.. 360 F.2d 977.996 (8th Cir. 1966). See generally' McConnell. supra note 95 , at 48-52. 
Even though the Supreme Court has indicated that the antitrust laws are not to be restricted by artificial limitations, ${ }^{101}$ thereby placing great trust in the jury to make the ultimate evidentiary conclusion, ${ }^{102}$ lower courts have still maintained the more restrictive directness test concerning who may sue under the antitrust laws. ${ }^{103}$ Since there has been no movement to give a private right of action based entirely on a violation of the antitrust laws, without regard to the injury suffered by the particular plaintiff-which would, in effect make every plaintiff a private attorney general ${ }^{104}$ - the causative link must still be examined. Therefore, setting standards for causation that requires a direct confrontation with the policy of the antitrust laws will yield a more rational resolution of the causation issue.

101. Radovich v. National Football League, 352 U.S. 445, 454 (1957).

102. See Zenith Radio Corp. v. Hazeltine Research,'1nc., 395 U.S. 100, 124-25 (1969); Continental Ore Co. v. Union Carbide \& Carbon Corp., 370 U.S. 690, 700-01 (1962),

103. See notes 22-30 supra and accompanying text.

104. See Slick Airways, Inc. v. American Airlines, Inc., 15 F.R.D. 175, 178 (D.N.J. 1954); Revere Camera Co. v. Eastman Kodak Co., 81 F. Supp. 325,330 (N.D. Ill. 1948). 
